\title{
LENGTH-WEIGHT RELATIONS OF PELAGIC FISH SPECIES FROM EASTERN REGION OF JAVA SEA, INDONESIA
}

\author{
Mat SALEH ${ }^{1}$ and Agoes SOEGIANTO ${ }^{12 *}$ \\ ${ }^{1}$ Study Program of Marine and Fisheries Biotechnology, Graduate and Post-Graduate School, \\ Universitas Airlangga, Kampus B, Surabaya, Indonesia \\ ${ }^{2}$ Department of Biology, Faculty of Sciences and Technology, Universitas Airlangga, Kampus C, Surabaya, Indonesia
}

Saleh M., Soegianto A. 2017. Length-weight relations of pelagic fish species from eastern region of Java Sea, Indonesia. Acta Ichthyol. Piscat. 47 (3): 307-309.

\begin{abstract}
The present work estimates length-weight relations (LWRs) of fish species from eastern region of Java Sea, Indonesia. The fishes were caught by purse seines. A total of 2461 specimens belonging to five families and 12 species were analysed: Caranx sexfasciatus Quoy et Gaimard, 1825; Decapterus russelli (Rüppell, 1830); Elagatis bipinnulata (Quoy et Gaimard, 1825); Megalaspis cordyla (Linnaeus, 1758); Parastromateus niger (Bloch, 1795); Selar crumenophthalmus (Bloch, 1793); Sardinella longiceps Valenciennes, 1847; Euthynnus affinis (Cantor, 1849); Rastrelliger kanagurta (Cuvier, 1816); Scomberomorus commerson (Lacepède, 1800); Sphyraena barracuda (Edwards, 1771); Lepturacanthus savala (Cuvier, 1829). The $b$ values of the LWRs ranged from 2.407 for Sphyraena barracuda to 3.510 for Lepturacanthus savala. The presently reported study is the first report on LWRs of pelagic fish species at least from eastern region of Java Sea. Five species of fish such as Decapterus russelli, Parastromateus niger, Rastrelliger kanagurta, Scomberomorus commerson, and Sardinella longiceps have been studied especially in western region of Indonesia. These data can be used for evaluation of the status of the investigated species.
\end{abstract}

Keywords: ichthyofauna, biometric relations, LWR, purse seine, growth, Madura,

Measuring individual body length and weight is a basic procedure in fisheries scientific studies. The length-weight relation (LWR) is a useful tool to predict the fish weight at a certain length (and vice versa), to compare biometric and morphological differences between fish species in the same taxonomic group, to analyse condition indices, to estimate the biomass of the fishery resources, to calculate the catch, and to assist in the fisheries management (Liousia et al. 2012, Moutopoulos et al. 2013, Das et al. 2015, Xu et al. 2016).

Eastern region of Java Sea at north of Madura Island, Indonesia is a traditional fishing ground for local fishermen. To our knowledge, very few studies have been conducted concerning the LWRs of pelagic fish species from this area.

The study was carried out in the eastern region of Java Sea at north of Madura Island $\left(6^{\circ} 00^{\prime}-6^{\circ} 50^{\prime} \mathrm{S}, 112^{\circ} 50^{\prime}-\right.$ $\left.114^{\circ} 10^{\prime} \mathrm{E}\right)$, Indonesia. Fish specimens were caught by purse seines (mesh size $5.0 \mathrm{~cm}$ ) during October-December 2016. Total length (TL, cm) and body weight $(W, \mathrm{~g})$ were measured to the nearest $0.1 \mathrm{~cm}$ and $0.1 \mathrm{~g}$, respectively. Isometric-allometric growth of fish was commonly calculated by the equation:

$$
W=a \mathrm{TL}^{b}
$$

which converted into its logarithmic expression:

$$
\log W=\log a+b \times \log \mathrm{TL}
$$

Parameters $a$ and $b$ were estimated by least squares regression (Ricker 1973), as was the coefficient of determination $\left(r^{2}\right)$. The slope $(b)$ is used to describe the three dimensional growth (i.e., length, width, and depth) of a fish: for $b=3$ growth is isometric, for $b<3$ is negatively allometric and for $b>3$ is positively allometric (Froese 2006).

A total of 2461 specimens belonging to five families (6 Carangidae, 1 Clupeidae, 3 Scombridae, 1 Sphyraenidae, and 1 Trichiuridae) and 12 species were analysed: Caranx sexfasciatus Quoy et Gaimard, 1825; Decapterus russelli (Rüppell, 1830); Elagatis bipinnulata (Quoy et Gaimard, 1825); Megalaspis cordyla (Linnaeus, 1758); Parastromateus niger (Bloch, 1795); Selar crumenophthalmus (Bloch, 1793); Sardinella longiceps Valenciennes, 1847; Euthynnus affinis (Cantor, 1849); Rastrelliger kanagurta (Cuvier, 1816); Scomberomorus

" Correspondence: Dr. Agoes Soegianto, Department of Biology, Faculty of Sciences and Technology, Universitas Airlangga, Kampus C, Surabaya, Indonesia, phone: (+62) 315936501, fax: (+62) 315936502, e-mail: (AS) soegiant@indo.net.id, agoes_soegianto@unairac.id, (MS) matsaleh0205@gmail.com. 
commerson (Lacepède, 1800); Sphyraena barracuda (Edwards, 1771); Lepturacanthus savala (Cuvier, 1829). LWR parameters with their descriptive statistics are given in Table 1 . The $b$ value of the LWRs ranged from 2.407 for $S$. barracuda to 3.510 for $L$. savala. Five species showed positive allometric growth and seven species demonstrated negative allometric growth. The coefficient of determination $\left(r^{2}\right)$ values ranged from 0.829 for D. russelli to 0.996 for $S$. barracuda.

The presently reported study is the first to provide LWRs of pelagic fish species caught by purse seines at least from eastern region of Java Sea at north of Madura Island. Some fish species such as D. russelli, P. niger, R. kanagurta, $S$. commerson, and $S$. longiceps have been studied especially in western region of Indonesia (Froese and Pauly 2017). A comparison with data from FishBase showed that the growth types ( $b$ values) of fish highly varied among species and locations (Froese and Pauly 2017). These differences in $b$ values can be attributed to a combination of one or more factors including: habitat, area, seasonal effect, degree of stomach fullness, gonad maturity, sex, health, preservation techniques, and differences in the observed length ranges of the captured specimens ( $\mathrm{Li}$ et al. 2013, Hossain et al. 2015, Tobes et al. 2016). The results of presently reported study are useful for evaluation of the status of the investigated species. They are also required as an important parameter in the fisheries management. This work can also serve as baseline data for species with no previous LWRs as well as for comparisons with future studies of marine fishes especially from Java Sea at north of Madura Island.

\section{ACKNOWLEDGEMENTS}

This study was supported by research mandate of the Airlangga University. We would like to express our thanks to all those who were involved in the collection of the samples and measurements.

\section{REFERENCES}

Das S.P., Swain S., Bej D., Jayasankar P., Jena J.K., Das P. 2015. Length-weight relationships of four cyprinid species in India. Journal of Applied Ichthyology 31 (3): 583-584.

DOI: $10.1111 /$ jai.12762

Froese R. 2006. Cube law, condition factor and weightlength relationships: History, meta-analysis and recommendations. Journal of Applied Ichthyology 22 (4): 241-253.

DOI: $10.1111 /$ j.1439-0426.2006.00805.x

Froese R., Pauly D. (eds.) 2017. FishBase. [Version 06/2017] www.fishbase.org

Hossain M.Y., Sayed S.R.M., Mosaddequr R.M., Ali M.M., Hossen M.A., Elgorban A.M., Ahmed Z.F., Ohtomi J. 2015. Length-weight relationships of nine fish species from the Tetulia River, southern Bangladesh. Journal of Applied Ichthyology, 31: 967969.

DOI: $10.1111 /$ jai.12823

Li Q., Xu R., Huang J. 2013. Length-weight relations for 20 fish species from the Pearl River, China. Acta Ichthyologica et Piscatoria 43 (1): 65-69.

DOI: 10.3750/AIP2013.43.1.09

Moutopoulos D.K., Ramfos A., Mouka A., Katselis G. 2013. Length-weight relations of 34 fish species caught by small-scale fishery in Korinthiakos Gulf (Central Greece). Acta Ichthyologica et Piscatoria 43 (1): 57-64.

DOI: $10.3750 /$ AIP2013.43.1.08

Liousia V., Batziakas S., Panagiotou N., Daouti I., Koutrakis E., Leonardos I.D. 2012. Length-weight relations of 22 fish species from the littoral zone of the eastern Ionian Sea, Greece. Acta Ichthyologica et Piscatoria 42 (1): 69-72.

DOI: $10.3750 / A I P 2011.42 .1 .09$

Table 1

Length-weight relations of fish species caught from Java Sea at north of Madura Island, Indonesia

\begin{tabular}{|c|c|c|c|c|c|c|c|c|c|c|}
\hline \multirow{2}{*}{ Family } & \multirow{2}{*}{ Species } & \multirow{2}{*}{$N$} & \multirow{2}{*}{$\mathrm{TL}[\mathrm{cm}]$} & \multirow{2}{*}{$W[\mathrm{~g}]$} & \multicolumn{6}{|c|}{ LWR parameter } \\
\hline & & & & & $a$ & $b$ & Growth & $r^{2}$ & $a$ CI95\% & $b$ CI95\% \\
\hline \multirow[t]{6}{*}{ Carangidae } & Caranx sexfasciatus $\mathrm{J}$ & 32 & $15.4-20.8$ & $48.7-125.4$ & 0.020 & 2.878 & $-\mathrm{A}$ & 0.909 & $0.007-0.053$ & $2.544-3.213$ \\
\hline & Decapterus russelli & 529 & $10.1-17.7$ & $8.9-52.6$ & 0.006 & 3.176 & $+\mathrm{A}$ & 0.829 & $0.004-0.008$ & $3.053-3.300$ \\
\hline & Elagatis bipinnulata $\mathrm{J}$ & 95 & $16.1-22.9$ & $40.1-83.3$ & 0.016 & 2.754 & $-\mathrm{A}$ & 0.928 & $0.010-0.026$ & $2.596-2.911$ \\
\hline & Megalaspis cordyla & 68 & $26.1-31.8$ & $278.1-499.1$ & 0.024 & 2.869 & $-\mathrm{A}$ & 0.899 & $0.011-0.052$ & $2.635-3.103$ \\
\hline & Parastromateus niger & 96 & $16.6-30.4$ & $100.3-544.2$ & 0.045 & 2.729 & $-\mathrm{A}$ & 0.936 & $0.028-0.071$ & $2.583-2.875$ \\
\hline & $\begin{array}{l}\text { Selar } \\
\text { crumenophthalmus }\end{array}$ & 228 & $9.1-23.2$ & $10.1-122.8$ & 0.007 & 3.173 & $+\mathrm{A}$ & 0.973 & $0.006-0.008$ & $3.104-3.242$ \\
\hline Clupeidae & Sardinella longiceps & 425 & $13.8-20.1$ & $6.8-73.4$ & 0.007 & 3.072 & $+\mathrm{A}$ & 0.894 & $0.005-0.009$ & $2.971-3.173$ \\
\hline \multirow[t]{3}{*}{ Scombridae } & Euthynnus affinis $\mathrm{J}$ & 397 & $20.1-35.9$ & $97.5-549.6$ & 0.026 & 2.782 & $-\mathrm{A}$ & 0.923 & $0.021-0.034$ & $2.704-2.862$ \\
\hline & Rastrelliger kanagurta & 385 & $13.0-26.0$ & $17.2-177.5$ & 0.003 & 3.390 & $+\mathrm{A}$ & 0.922 & $0.002-0.004$ & $3.291-3.489$ \\
\hline & $\begin{array}{l}\text { Scomberomorus } \\
\text { commerson }\end{array}$ & 94 & $38.0-58.6$ & $298.2-989.8$ & 0.011 & 2.832 & $-\mathrm{A}$ & 0.922 & $0.006-0.021$ & $2.663-3.001$ \\
\hline Sphyraenidae & Sphyraena barracuda $\mathrm{J}$ & 31 & $23.0-36.6$ & $72.3-221.8$ & 0.038 & 2.407 & $-\mathrm{A}$ & 0.996 & $0.032-0.046$ & $2.349-2.464$ \\
\hline Trichiuridae & Lepturacanthus savala & 81 & $26.1-46.9$ & $11.4-75.7$ & 0.000 & 3.510 & $+\mathrm{A}$ & 0.930 & $0.000-0.000$ & $3.297-3.724$ \\
\hline
\end{tabular}

$N=$ number of fish in sample, $\mathrm{TL}=$ total length measured to nearest $0.1 \mathrm{~cm}, W=$ body weight measured to an accuracy of $0.1 \mathrm{~g} ; \mathrm{J}=$ all specimens used were juveniles; $a=$ intercept, $b=$ slope, Growth $=$ growth type, $\mathrm{CI}=$ Confidence interval, $r^{2}=$ coefficient of determination; $-\mathrm{A}=$ negative allometric growth, $+\mathrm{A}=$ positive allometric growth. 
Ricker W.E. 1973. Linear regressions in fishery research. Journal of the Fisheries Research Board of Canada 30 (3): 409-434.

DOI: $10.1139 / \mathrm{f} 73-072$

Tobes I., Miranda R., Pino-del-Carpio A., AraujoFlores J.M., Ortega H. 2016. Length-weight relationships of freshwater fishes of the AltoMadre de
Dios River (Manu Biosphere Reserve, Peru). Journal of Applied Ichthyology 32 (6): 1256-1258.

DOI: $10.1111 /$ jai.13172

Xu H.-L., Gu D.-X., Wang R., Qi H.-L., Guo L., Qiao X.-T. 2016. Length-weight relationships of five Gobiidae species from Bohai Bay, China. Journal of Applied Ichthyology 32 (5): 998-999.

DOI: $10.1111 /$ jai.13149

Received: 1 February 2017

Accepted: 6 June 2017

Published electronically: 30 September 2017 